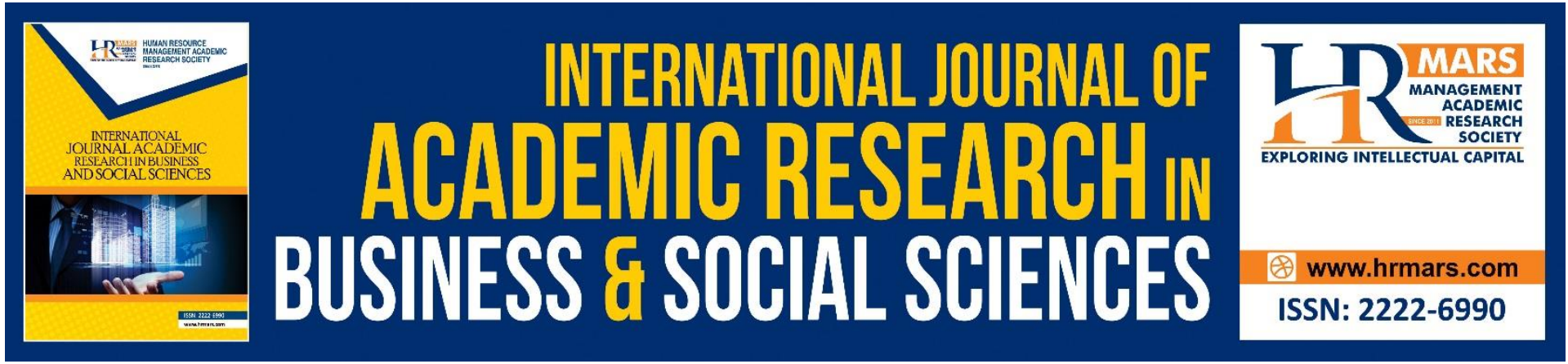

\title{
Malaysian Fresh Graduates' Performance in Job Interviews: Politeness Strategies
}

Nalini Arumugam, Isai Amutan Krishnan, Geraldine De Mello, Mohammad Nor Afandi bin Ibrahim, Puspalata C Suppiah

To Link this Article: http://dx.doi.org/10.6007/IJARBSS/v11-i9/11089

DOI:10.6007/IJARBSS/v11-i9/11089

Received: 09 July 2021, Revised: 30 July 2021, Accepted: 17 August 2021

Published Online: 12 September 2021

In-Text Citation: (Arumugam et al., 2021)

To Cite this Article: Arumugam, N., Krishnan, I. A., Mello, G. De, Ibrahim, M. N. A. bin, \& Suppiah, P. C. (2021). Malaysian Fresh Graduates' Performance in Job Interviews: Politeness Strategies. International Journal of Academic Research in Business and Social Sciences, 11(9), 975-990.

Copyright: (c) 2021 The Author(s)

Published by Human Resource Management Academic Research Society (www.hrmars.com)

This article is published under the Creative Commons Attribution (CC BY 4.0) license. Anyone may reproduce, distribute, translate and create derivative works of this article (for both commercial and non-commercial purposes), subject to full attribution to the original publication and authors. The full terms of this license may be seen

at: http://creativecommons.org/licences/by/4.0/legalcode

Vol. 11, No. 9, 2021, Pg. 975 - 990

Full Terms \& Conditions of access and use can be found at http://hrmars.com/index.php/pages/detail/publication-ethics 


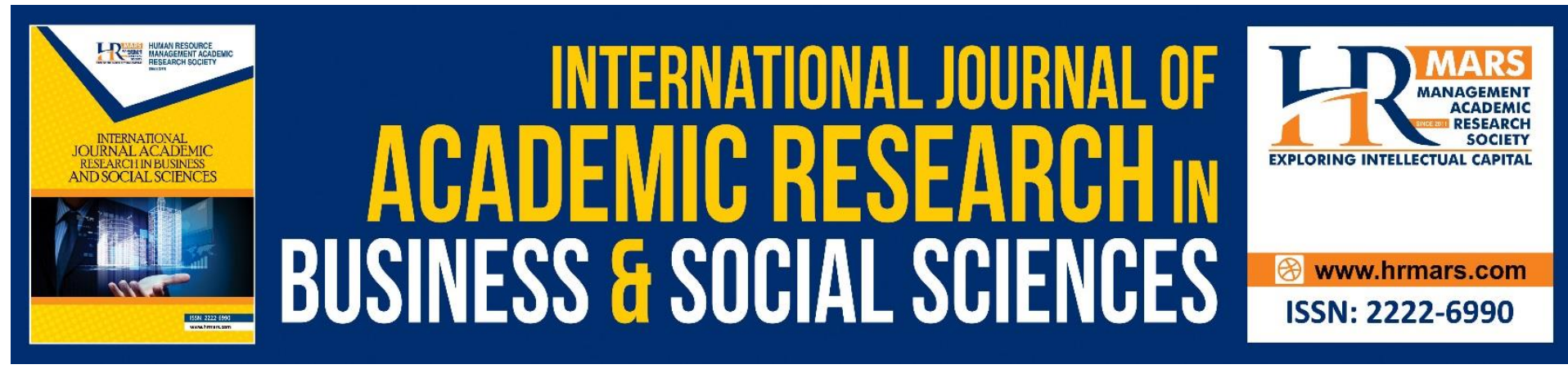

\title{
Malaysian Fresh Graduates' Performance in Job Interviews: Politeness Strategies
}

\author{
Nalini Arumugam ${ }^{1}$, Isai Amutan Krishnan², Geraldine De Mello ${ }^{3}$, \\ Mohammad Nor Afandi bin Ibrahim ${ }^{4}$, Puspalata C Suppiah ${ }^{5}$ \\ ${ }^{1,5}$ Academy of Language Studies, Universiti Teknologi MARA Shah Alam, Selangor, Malaysia, \\ ${ }^{2}$ Faculty of Languages and Linguistics, University of Malaya, ${ }^{3,4}$ Academy of Language Studies, \\ Universiti Teknologi MARA Melaka, Malaysia \\ Email: geraldine@uitm.edu.my
}

\section{Abstract}

Face-to-face interaction is a process of personal interaction in expressing opinions and answering questions, as in job interviews to evaluate the suitability of interviewees in a hiring process. Although educational institutions in Malaysia have introduced measures to provide fresh graduates with the required interactive competences, yet there are still incapable of carrying out proper interactions in job interviews. Therefore, the purpose of the study was to investigate the use of politeness strategies in job interviews. Twenty fresh graduates and five human resource managers from prominent outsourcing organisations participated in the study. Job interview data were recorded, transcribed, and analysed qualitatively to identify politeness strategies used in the interviews. The findings show that two positive politeness forms were identified: "paying attention and focusing on interviewer's concerns, requirements, wishes or gains", and "constructing/emphasizing shared positions to build commonality". One negative strategy was found, "asking for explanation or repeating". The findings further revealed that most of fresh graduates were not able to carry out smooth interactions and unable to use impression management tactics with the interviewers during the job interviews. They study may contribute significantly for the course module by integrating politeness strategies in job interviews on face-to-face interactions in employment programs.

Keywords: Fresh Graduates, Politeness Strategies, Job Interviews

\section{Introduction}

Job interviews are assessments for getting jobs. Whilst the job interview procedures may involve several phases, the first interview is usually the phase where the conduct and character of the interviewee is assessed by the interviewer to decide on the suitability of the individual to be recruited by the institution. Private as well as government sector studies have revealed that interviewers prefer individuals who are analytical, logical, responsible and are able to communicate their ideas clearly (MHEM, 2014; Azwan, 2018). It is also emphasised that interviewers would "regard graduates interaction skills and the way they depict themselves as carrying more weight that information provided in the CV, hence having adequate interactive capability can enhance individuals' to present heightened self-assurance 
(Valerija, 2010; Selvaratnam, 2018). This confirms that good interaction is a significant feature to portray a confident personality, which is an essential part of impression management (Tanius et al., 2019).

With the implementation of the National graduate employability blue print 2012-2017 with its focus on upgrading Malaysia into an advanced nation by boosting human capital benchmarks, the Higher Education Ministry directed that one of employability skills, which is English language proficiency (hereafter proficiency) component need to be integrated in the employment curriculum for undergraduates in Malaysia due to two important considerations (Arezoo et al., 2019). Firstly, input from the employment sector has indicated that students educationally well-equipped but lack proficiency and secondly, competition in the employment sector has intensified due to globalisation (Ministry of Higher Education Malaysia, 2014), a good proficiency is required for the global employment market workforce (Chun et al., 2012; Yetty, 2018; Chiara \& Magali, 2019).

However, fresh graduates still face difficulties in articulating effectively in job interviews, resulting in painting a negative picture of themselves and are unlikely to be suitable for employment. Research carried out by Majid et al (2020) indicates that graduates proficiency has better prospects to be employed than those who were poor in proficiency. Many of these fresh graduates' lack effective interaction in English during interviews lose out on job prospects, particularly in the commercial area. This could be an attestation of disconnect between what the educational system is delivering and the requirements of the employment sector (Tejan \& Sabil, 2019). In fact, a review of certain English for Specific Purpose (ESP) programs in some public educational institutions locally has indicated the existence of a disparity between what is provided to these graduates at the university prior to their leaving and the urgent English requirements after they leave (Sarfraz et al., 2018). Therefore, the purpose of the study was to investigate the interaction of job interviews pertaining to the face-to-face interaction of politeness strategies ascertain the extent to which fresh graduates were effective in answering the questions asked of them and performed effectively predictably depicted an optimistic self-portrait.

\section{Literature Review \\ Politeness theory}

Politeness strategies were derived from the framework of Brown and Levinson (1987) that focussed on face-to-face interaction in various languages. Goffman (1999) classified politeness strategies into positive and negative faces based on Brown and Levinson 's framework. The positive face is defined as "the necessity to be acknowledged, even adored by others" (Yule, 2008, p.61) and focuses on their desires and actions that Brown and Levinson (1987, p. 328) described as "approach based". Negative face, is defined as the requirement to be unconventional as well as free of encumbrances and not to be controlled by others" (Yule, 2008, p. 61; Parisa et al., 2012; Iman, 2018). As a result, negative face is an "evasion-centred" action and "focused primarily".

Based on the framework, politeness strategies are conducted to diminish facethreatening acts (FTA) that can endanger the positive/ negative face of the orator/listener, if these actions are to take place. By considering "the need to convey the substance of the FTA.... the desire to be effective or earnest.....and the need to sustain H's [hearer's] facet any extent" (Brown \& Levinson, 1987, p. 211), a person would openly (on record) or implicitly (off record) conduct the FTAs. A forthright FTAs can be implemented either in the "absence of politeness behaviour acts" or "through politeness behaviour acts" (p. 245). Brown and Levinson (1987, 
p. 211) have indicated that the selection of particular approaches to apply would include the appraisal of the importance of the FTAs cantered on the concern of the "social distance" between speaker and listener, "relative power" between presenter and listener, and the "complete classification of requirements of the specific society" (cited in Abdullah Ahmed et al. 2015; Ivana, 2017). This framework postulates that it is possible to assume that there exists a broad societal gap between the interviewee (talker) and the interviewer (listener) as this is their initial face-to-face meeting. The interviewer can be assumed to be dominant and thus is able to execute his appraisal or manage events, while the level of enforcement would be contingent on the overall prospects at an employment interview in the Malaysian setting

Based on the studies discussed above, it has been found that in job interviews, it is normal for interviewers and interviewees to have scant knowledge about one another. First interviews are usually quite brief and this gives little time to the interviewer to make a comprehensive evaluation of a candidate which is vital to the overall success of the recruitment procedure. Amongst the reasons mentioned that tend to influence interviewers' assessments are academic credentials, job knowledge, ethnicity, age, race and managing selfimage (Goffman, 1999). Therefore, this study will investigate the face-to-face interactions in interview settings.

Interview is a platform where the interviewer and interviewee claim a 'common ground' to imply that both of them belong to the same group who share similar interests and desires (Amer et al., 2020). They further explained that when interacting with the interviewee, one can gauge a picture of the candidate's competence, confidence and ability by their responses as well as uses of the language. Gusti et al (2018) shared that use of politeness strategy can reduce the gap between people with higher and lower power. They revealed that practising politeness strategy in classrooms can enhance the teaching and learning processes as well as improve teacher-student interactions by reducing imposition and indirectness. This leads to having respectful communications that consequently materializes in a meaningful teaching and learning process. Ambele and Boonsuk (2018) highlighted that the use of politeness strategy is influenced by one's culture. They indicated that poor language proficiency and uncertainty in word usage from an interlocutor can cause a change in hearer's mood. Some may choose to use silence as a face-saving politeness strategy.

\section{Methodology Setting}

Consents were obtained from an outsourcing organisation as well as the job candidates. Data were collected from the prominent outsourcing organisation, that is located in the city of Kuala Lumpur. This organisation creates job opportunities for fresh graduates as it will only hire fresh graduates for employment and has been providing this service for over 15 years.

\section{Participants}

Twenty fresh graduates aged between 23 and 25 and five human resource managers participated in this study. The fresh graduates were from public universities and had graduated from various courses such as business administration, human resource management, marketing and economics. As for the human resource managers, they were experts in job interviews and training providers from outsourcing organisations in Malaysia. They were also involved in conducting workshops on job interviews for undergraduates in public and private universities. 


\section{Data Collection and Analysis Procedures}

The interview data were collected in the organisation. In order to attend the interviews, the interviewees had to sit for an English placement test that consisted of eighty multiple choice questions and twenty structured questions pertaining to the English language such as tenses, parts of speech, vocabulary and sentence structures. Those who obtained a score of eighty and above were called to attend this interview. Out of a hundred and twentyfive interviewees, only twenty were selected for the interview. The interview duration for each interviewee was between 20 and 25 minutes. The interview questions asked were related to self-introduction, strengths and weakness, purpose for hiring, objectives in 5 years' time, and stress management problems. The recorded interview data were transcribed and analysed based on Jefferson's (2004) transcription notation symbols and Brown and Levinson's (1987) politeness strategies. The coding was done using NVIVO version 12 . The verification was done by three experts from languages and linguistics. Wodak (2013) noted that one sample of utterance would be significant for a qualitative study, as in job interviews as per objective of the study. In-depth interviews were conducted with interviewees and were triangulated with the feedback from the human resource managers. The interviewers are referred to as IR (IR1, IR2, etc) while interviewees as IE (IE1, IE2, etc).

\section{Analysis and Discussion}

The finding presents the Positive and Negative politeness strategies. The analysis starts with the positive politeness strategy followed by the negative politeness.

\section{Positive Politeness Strategies}

Two politeness strategies were found; (i) paying attention and focusing on interviewer's concerns, requirements, wishes or gains' and (2) constructing/ and shared positions to build commonality based on Brown and Levinson's (1987) framework. These two strategies are utilised to illustrate that, the speaker (interviewer in this study) "desires" the same thing as that the listener (interviewee in this study) "desires". Consequently, the gap between them reduces and the listener and the speaker have mutual ground where the listener is respected and regarded as the speaker's circle. This is regarded as conformance to the listener's positive face. Nevertheless, it is noteworthy that these strategies are observed in the job interview according to the societal fluctuations of the condition (societal space, comparative influence and status) including the framework of the job interview. In this context, the interviewer who acts as the listener does not need recognition or endorsement. The interviewee on the other hand, is in need of recognition and appreciation in order to be selected for the job.

The purpose of these two strategies vary marginally when applied to our findings. Brown and Levinson (1987) suggested that the interviewee endeavours to underscore the likeness between self and the interviewer. The interviewees do not show preference for the interviewer but attempt to gain recognition and secure the trust of the interviewer. This is apparent in sample occurrences.

Paying attention and focusing on interviewer's concerns, requirements, wishes or gains'

\section{Excerpt 1}

IR "So ok, if you are caught with the difficulty what will you do?" 
IE1 "What should I do if the people [with a] hot temper deal with me? I will listen to them and I may refer to the boss".

The interviewee had to comprehend the questions asked by the interviewer and answer appropriately. Excerpt 1 is an example of the way IE1 recognises the question asked by the interviewer, and then provides a clear and appropriate response.

\section{Excerpt 2}

IR you enjoy the audit. do you expect yourself performing this for the ensuring 10 years in your career?

IE2 Hmm... I may go for auditing ...mmm

IR ok certainly this is the where there is position of audit you can focus in just preparing audit in your life.

Excerpt 2 by contrast, is an example where the IE2 did not offer a proper reply. Hesitancy in replying to the question, pausing often, prolonged fillers (Emise et al., 2018) and using meaningless words revealed her inability to comprehend the question (Iman, 2018). This triggered exasperation on the part of the interviewer that was revealed from the face-to-face interaction and repetitions. Tanius, et al. (2019) suggest that proficient interaction and knowledge are two crucial issues that create assurance and feelings of honesty and this ensures a favourable outcome of an interview (Kerekes, 2006). Consequently, interviewees need to offer extra data that pertains to the question for example by providing many details instead of giving brief answers as can be seen in Excerpt 3.

\section{Excerpt 3}

IR yes like what type of skills experience abilities and you will require

IE3 well...

IR for the past 10 years you intend to set up your own business that will

IE3 leadership abilities management and then certainly information is very crucial

IR Ok

IE3 and then ... the very crucial I feel is uh networking

IR hmmm,

In Excerpt 3, IE3 mentions a few abilities required to set up a business but fails to explain or give more constructive facts, when compared to IE4 as in Excerpt 4, IE 3 gave justifications for her answers.

\section{Excerpt 4}

IR well...what do you want yourself to be? Because you have only been subjected to tax and what about audit and book keeping?

IE4 Audit is better job I would say and I can enhance my knowledge work towards the organisation's vision and mission and them later I start up my own.

IR hmmm...

IE4 ...audit really is a good but I favour on tax more than audit

IR hmmm... 
IE4 but I may prefer to do auditing job for some to gain some working experience then I may consider to other track

From the above Excerpt, IE4 reveals s/he has the skills required to perform particular jobs but can also 'fit' into the prevailing culture of the firm that cannot be gauged from the resume. Hence, by answering the questions, the interviewees are adhering to the interviewer's requirements, thereby displaying the politeness strategies.

The strategy of acceding to the interviewer's requirements, desires, and preference like responding negatively can be configured into a type of constructive courtesy approach. Such configuration is present is Exerpt 5

\section{Excerpt 5}

IR well... what... what do you desire to be in like 10 years from now in your life?

IE5 10 years...10 years ...

IR in 30s and 40s...

IE5 I figure I may start up my own business as I may not able to work with others

IR hmmm...

IE5 hmmm=

IR well do you think you could really uh just go and uh immediately start your own business

IE5 I think I need to gain working experience which is essential but...but...I must have a good network without really having to work in an organisation like this?

IR I see

IE5 I see

IR oh...that's cool and do you disturb by that

When questioned on IE5's plans for the next 10 years, she stated her intention was to start her own enterprise, which triggered the interviewer to enquire her purpose to enter the business world. IE5 without hesitation disagreed but gave an explanation for wanting to enter business and explained her views by giving an example. As a result, she has succeeded to show herself as an individual who has contemplated regarding her future. This attitude has satisfied the interviewer.

Therefore, by agreeing or disagreeing, interviewees get a chance to give their ideas, thus revealing their ability to think critically and, objectively with clarity (JobStreet, 2014) that are all crucial points that interviewers look for when interviewing individuals. Therefore, in this case, differences can be viewed as a strong positive politeness.

\section{Constructing/emphasising shared positions to build commonality}

Kerekes (2006) suggests cohesion and like-mindedness between the interviewer and interviewee establishes confidence. Indeed, this connection is developed while the interview progresses. Positive politeness strategies like presuming/highlighting/stressing and shared positions are indicators that can be used by interviewees to create friendship with the interviewer. All the participants in this research endeavoured to emphasise shared positions and apply coterie character indicators by including technical genres to express their expertise in the specific disciplinary matters as shown in Excerpt 6. 


\section{Excerpt 6}

IR ok explain me some of your skills when you were in this uh organisations. What...what did you do and what did you achieve from that experience that you possess

IE6 well...beginning... I join the one of the Management organisations hmmm they accept me train me uh taught me how to enter the information from the documents to into the accountings uh computerised process.

IR alright

IE6 and then hmmm I study a software called...in the organisation...

IR =Ok.

IE6 and later...hmmm when I go to the audit year hmmm SMC organisation ...

IR I see

IE6 Hmmm then...I was able to utilise it when I study in the

IR alright...then you were beginning to use the Blind System in the company ...I mean in SMC

IE6 ya I hmm... when join SMC I study another software express system

IR I see

IE6 that's the reason I know how to use in SMC which is a classy

When questioned regarding her employment experience, IE6 explained her skills in 'software system' and 'Blind System' in the management area and this captured the interviewer's attention. More than that, IE6 also persisted in asserting shared interest by mentioning her employer 'SMC' when describing her goals, as revealed in Excerpt 7.

\section{Excerpt 7}

IE6 Hmmm.... I intend to start the audit firm

IR I see....

IE6 Like my manager...SMC

IR I see

IE6 they established their own organisation efficiently... I would like to follow their foot steps

Further, positive politeness strategies are actions revealed as a response to the awareness and attention of the other individual and also to assert a certain similarity between them (Azwan, 2018; Chiara \& Magali, 2019). Graduates in job interviews may experience challenges in recognising the same shared basic knowledge in the early stages of the interview. However, they could exhibit alertness and vigilance on subjects or facts that attract the attention of the interviewer. It is important to capitalise on these shared interests as generalised in Excerpt 8

\section{Excerpt 8}

IR well...no it... It's exiting your work in a supermarket and you even now want to return to supermarkets ya It's fairly exiting.

IE7 on occasion hmmm...in Mega Mall... I plenty of tension too.

IR I see

IE7 work as cashier cause in Mega Mall every daily uh the plastic bag is need to pay

IR I see 


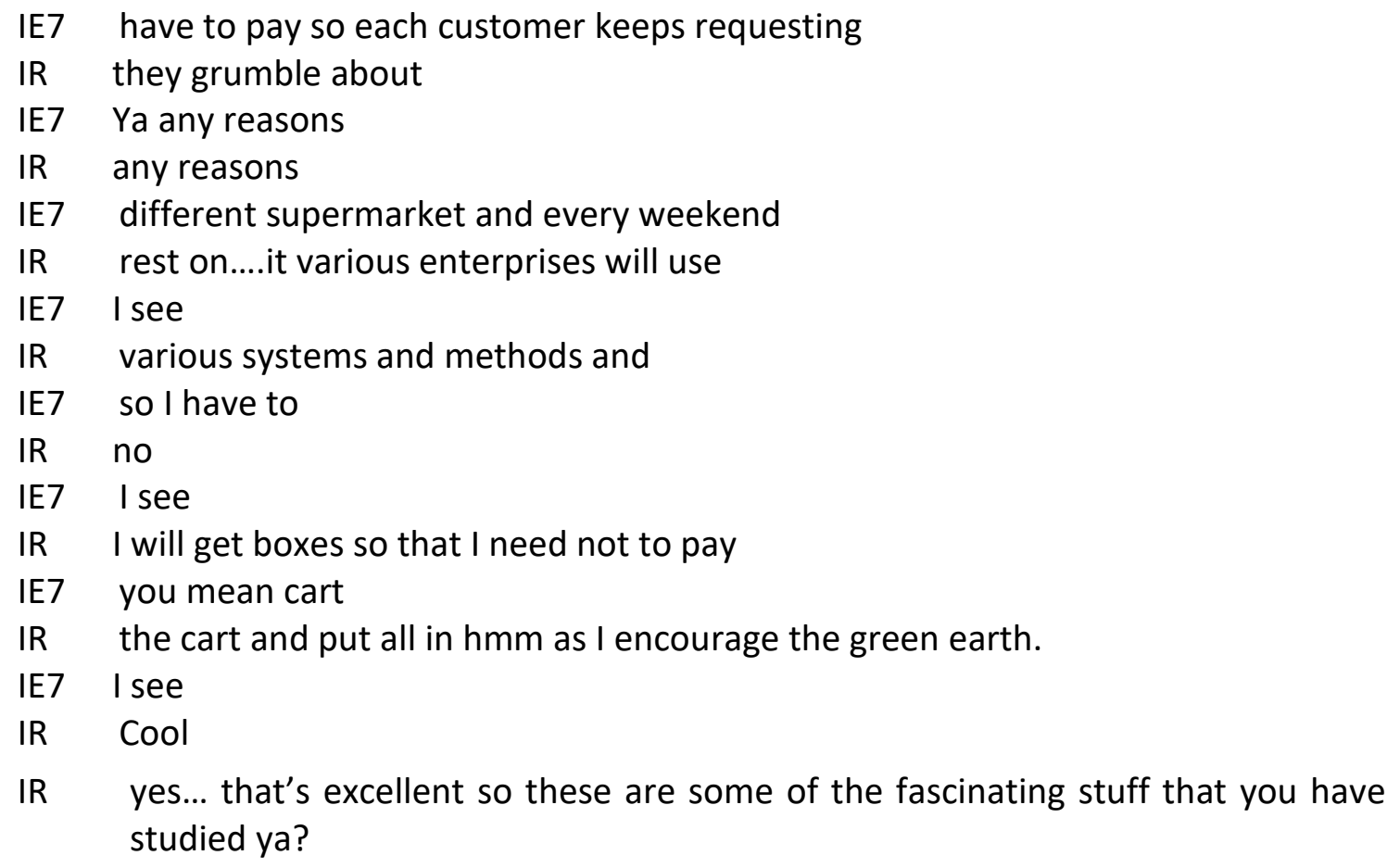

In Excerpt 8, IE7 revealed her knowledge as an employee in the Mega Mall (shopping Complex) that captured the attention of the interviewer who frequented it. It has been observed that IE7 reiterating this subject of mutual interest and brought it out again. The interviewer remarked on it but it didn't require a response from IE7. IE7's effort surprised the interviewer that momentarily side-tracked the proper interview into an informal discussion on a private matter. This is comparable to what Kerekes (2007) recognised as a light-hearted conversation based on mutual interest though it has no relevance to the job interview.

\section{Negative Politeness Strategies}

When the interviewer's endurance is tested, negative politeness is the main problem encountered by the interviewees who seek explanation or repetition. Brown and Levinson (1999) pointed out that appeals made while interviews are in progress can be regarded as a risk to the adverse face. Kerekes (2007) postulated that interviewees often were compelled to request the interviewer for explanation and their mode ranged from restating to confessing and not to understand. Likewise, in this study restating and confessing were also discovered. When explanation appeals were studied, adverse courtesy approaches like evasiveness, aloofness, and expressions of regret were recognised.

\section{Excerpt 9}

IE8 ok...can you say it again...

IR what will be ah one of the main challenge when you join a company like us meaning that what kind of problems you will have to deal with

IE8 alright

IR You have stated that one aspect would be you are ready to relocate from your place in a bit far place to be here. What would be other matters that you think you will be discovering that hard to cope

IE8 oh...I do not know what to say 
IR Like for instance uh you will likely have to refer to reading materials

IE8 I see

It can be observed in Excerpt 9, that IE8 used the second person pronoun 'you', which openly exhibits that IE8 was obliging to the interviewer's request. Nevertheless, IE8 corrected his open appeal by speaking in an artful manner by having fillers like spaces and breaks in his reply.

\section{Excerpt 10}

IR correct what do you think it will take to set up a company like Adrian Yeo and company

IE9 my apology

IR what do you think it will require for you to set up a company like

IE9 hmm you mean my job

IR what type of insight, discovery, abilities and facts that you will require

IE9 abilities of leader, supervision...hmmm and then of course experience is very crucial right

IE9 did not directly appeal to the interviewer to repeat or explain his question but expressed an apology which showed a similar rhetoric to appeal. This resulted the interviewer to respond by providing the necessary repetition and explanation.

It is of interest to observe that in the appeal for explanation, the second person pronoun 'you' (impersonalised) is not used, hence the interviewer did not feel obligated to fulfil the request. In doing so, the interviewer obtained "conscionable way to avoid, allowing him to assume that his reaction is not forced" as mentioned by Brown and Levinson (1987, p 211). Repeating explanation appeals were common input, in question forms as well as comments, as illustrated in Excerpt 11.

\section{Excerpt 11}

IR what is your professional ambition in this?

IE10 work ambition

IR What do you aim to be in 10 years' time

IE10 hmmm...

IR where do you see yourself?

IE10 I see myself as I mean in 10 years' time I would like to be an executive post to see myself in a well-known organisation.

There were also cases where the interviewee would make an open appeal in the absence of reciprocity (Example 12). Although this overture was impersonal, the phrase 'comes again' can be considered as an open appeal because of its "straightforward obliqueness" (Brown \& Levinson, 1987, p. 256).

\section{Excerpt 12}

IR what do you think you will require between now and then?

IE11 say it again

IR What would you like to do in 10 years

IE11 money first and then skills, my networking and my colleagues 
An interesting consideration though, is the fact that acknowledgement was not always forthcoming from the interviewees for the assistance rendered by the interviewer. Taking into account the fact that the interviewees were disrupting the interviewer by requesting for explanation or reiteration, it would be in order that after asking a favour from the interviewer, the interviewees would convey their thanks. In Excerpt 9, IE8 communicated by using a filler 'oh' accompanied by 'ok', that indicated that he understood the question but failed to accept the interviewer's help. In examples Excerpts 10 and 12, there is no indication of gratitude, regret or admission. The interviewees continued to give their answers, ignoring the displeasure demonstrated by the interviewer with discouraging or rejecting facial expressions. Looking at the information, it is clear that there was an absence of negative politeness strategies. The strategies as explained above are important, as various reasons can be inferred from them. The next section will discuss the possible inference strategies.

\section{In- Depth Interview with Human Resource Managers}

The Human Resource Managers (HRMs) revealed that most interviewees did not use impression management tactics (IMTs). The use of IMTs in interviews can create a desired image of oneself by presenting their past accomplishments. For example, they were asked to talk about themselves, some of the interviewees provided irrelevant responses; IE3, started talking about her family background, and siblings

"I live in KL with my parents and my siblings"

As an interviewer I would expect IE1 to talk about her accomplishments to reveal her credentials.

Another example was IE10 who tried to secure the position by associating herself with one of the high-ranking personnel in the organisation. Thus, giving an indication to the interviewer that she should be absorbed into the organisation.

"you know the managing director is my dad's close friend, he was the one who recommended me to apply this position"

This is an inappropriate strategy used by the interviewee to impress the interviewers in their decision making. Similarly, it was also obvious when IE8 responded "oh...I do not know what to say". This shows that he did not reveal much interest in securing the job. IMTs provide positive impression by reducing the prominence of an under-rated social identity.

None of the interviewees has used self-promoting utterances to show that he or she has desirable qualities for the job applied as this can help to evoke attributes of competence the interviewees used nonverbal body language to create an impression of closeness like laughing, looking away from interviewer and making eye contact. Furthermore, the HRMs also indicated that IE10 did not use good listening skills. However, s/he used body language like nodding affirmatively (E10).

A few applicants displayed superiority in their responses and intentionally avoided eye contact. During job interviews, IMTs were not used, though it would have increased the chances of being hired. IE8's response showed a negative attitude to the interviewer especially when she said "I didn't know I should bring my original certificates".

Apart from IMTs, the HRMs also reported that most of the fresh graduates were not confident in responding to the questions posed during the interview. This is due to poor English language proficiency in pronunciation, use of inappropriate vocabulary and grammar and word orders as can be seen in the excerpts from 1-12. 


\section{Discussion}

The present study reveals the need to teach courtesy approaches to enhance interviewees competence. First, we discovered that generally, interviewees understood and provided acceptable answers put to them by the interviewers, acknowledging the importance of being attentive and fulfilling to the requirements and expectations of the interviewer.

Nevertheless, a number of interviewees were unable to provide further details regarding themselves. Furthermore, we hypothesise that the avoidance of differences is a kind of constructive courtesy approach in Brown and Levinson's (1987) opinion, differences and contradictions can develop positive face centred on facts that are "given-off" (Goffman, 1959) rather than depend on that are 'given'.

Lipovsky (2006, p.1149) also explains that "The interviewer's appraisal is influenced based on the technique used by the interviewee than the details provided. This explains that the interviewees' skillfulness in presenting impacts the interviewers' 'assessment of them". In this instance, Kerekes' (2007) contention appears to hold water, from an assessment of the reactions of the interviewer previously in Excerpt 2 when compared to Excerpt 8. Thus, interviewees need to pay greater attention and be aware of what interests the interviewer (constructive courtesy approach) while the interview is in progress and take advantage of the perceived opening. Students have to realise that attending interviews is not answering questions but more of a robust exchange of ideas, between two speakers.

Lastly, we recognised that the students may be unable to show or apply the politeness strategies

in carrying out the interaction with interviewers by asking for explanation or replication. Based on our information, we ascertained that students created multiple approaches to lessen the 'command' consequence of their appeal, that indicated their awareness of the appeals directed to the interviewer. Nevertheless, they were unsure of actions to follow after making a threat, particularly if no atonement was made before the intimidation. Students should be sensitised to the fact that when the interviewer clarifies or the question is repeated, he is in essence sacrificing his 'face' and in a way "doing favours" by helping the candidate to cooperate (Shaari et al., 2019). Meanwhile, in face-to-face interaction the interviewee is expected to collaborate and respond to the comparable politeness strategies. It is therefore essential for students to study and utilise politeness strategies in order to create a meaningful interaction, as in job interviews. Based on the in-depth interviews with HRMs, we can conclude that politeness strategies are one of the important components in job interviews to secure employment. Taking into account the productively globally, it is necessary to understand politeness in professional communication

\section{Implications of the Study}

This study may benefit undergraduates, educators and curriculum designers who are dealing with Pragmatics as a subject. Policy makers may integrate politeness strategies to prepare 'school leavers' to meet the workplace demand in fulfilling their needs. The results may also be useful for upcoming researchers to consider politeness strategy particularly and pragmatics in general. Additionally, media representatives and public figures can benefit from this study to have an in-depth understanding in hosting and responding to interviews.

Another contribution of the study is polite interaction is one of the ways to know new people. Polite interaction, may be helpful in creating a positive impression of the applicant. This first impression may be a good form of introduction that can lead to a successful 
interview. The use of polite words by the applicant is also an indication of his/her cultural background.

Although this study has been conducted in Malaysia it would also benefit other English-speaking countries as most industries or organisations use English as a medium of communication. Future studies on politeness strategies should look into different sectors as well as experienced candidates who attend interviews. It is hoped that the findings from this study would improve perceptive on language use and communication.

\section{Limitations of the Study and Further Studies}

One limitation of this research is that these interviewees may not have made conscious use of politeness strategies for creating good impressions. Future research should evaluate the students' IMTs (Goffman, 1999) in job interviews. They can be integrated with communicative behaviour (Allwood, 1999) to analyse how fresh graduates carry out their interactions with good English language proficiency. The proficiency that entails in relation to pronunciations, use of appropriate vocabulary and grammar particularly in the sentence structures and word orders. The study adopted western politeness strategies where people are homogeneous but the interviewees still tend to use their mother tongue mostly. It would be useful to discover English language instructors' attitude towards the politeness strategy as some interviewees acquired the skills through browsing the websites.

\section{Conclusion}

It was observed that the interviewees were able to display politeness strategies in the interview by showing signs of welcome and acknowledging the value of time to the interviewer though they may not be consciously adopting the identified politeness strategies for impression management purposes. Nevertheless, the intense competition for employment among graduates in Malaysia, (students and instructors as well), the politeness strategies could be applied in job interviews in order to carry out professional interactions that create a favourable impression in the employers.

\section{References}

Allwood, J. (1999). Are there Swedish patterns of communication? In H. Tamura (Ed). Cultural acceptance of CSCW in Japan and Nordic Countries (pp. 90-120). Kyoto Institute of Technology. https://www.researchgate.net/publication/2441775

Amer, F., Buragohain, D., \& Suryani, I. (2020). Politeness Strategies in Making Requests in Jordanian Call-Centre Interactions. Education and Linguistics Research, 6(1),69-86. http://www.macrothink.org/journal/index.php/elr/article/view/16283

Ambele, E. A., \& Boonsuk, Y. (2018). Silence of Thai Students as a Face-Saving Politeness Strategy in a Multicultural University Context. Arab World English Journal (AWEJ),9(4), 221-231. DOI: https://dx.doi.org/10.24093/awej/vol9no4.16

Arezoo, K., Behzad, G., Zargham, G., \& Reza, G. (2019). Relationship between students' gender and their use of politeness strategies in the results and discussions section of PhD dissertations. DINAMIKA ILMU, 19(1), 75-95.

https://files.eric.ed.gov/fulltext/EJ1217894.pdf

Azwan. (2018). Politeness strategies of refusals to requests by Ambonese community. Lingua, 15(1), 1-6. http://lingua.pusatbahasa.or.id 
Brown, P., \& Levinson, S. (1987). Politeness: some universals in language usage. https://www.academia.edu/26395652/Politeness_Some_universals_in_language_usa ge

Chiara, S., \& Magali, C. (2019). Soft skills to enhance graduate employability: comparing students and employers' perceptions, Studies in Higher Education, 1(2),1-15. https://srhe.tandfonline.com/doi/abs/10.1080/03075079.2019.1585420?needAccess= true\#.X31-UFLivIU

Emise, K. M., Cyrus, N., Lilian, O., Kaberia, I. K. (2018). Politeness strategies in Gichuka request expressions. International Journal in Management and Social

Science, 6(7),167-194.

https://www.academia.edu/38729966/POLITENESS_STRATEGIES_IN_GICHUKA_REQU EST_EXPRESSIONS

Farida, F. \& Yuliana, D. (2019). Politeness strategies in WhatsApp text messaging between Sundanese students and lecturers. Advances in Social Science, Education and Humanities Research, (257),172-175. https://www.atlantispress.com/proceedings/icollite-18/55915094

Feryal, C. (2017). An interlanguage pragmatic study of politeness strategies in Turkish and English. An Interlanguage Pragmatic Study of Politeness, 49-57. http:// DZ 177.1(811.512.161:811.111)=111

Goffman, E. (1999). On face-work: An analysis of ritual elements in social interaction. In A. Jaworski \& N. Coupland (Eds.), The discourse reader (pp.306-320). Oxon, OX: Routledge. https://doi.org/10.1080/00332747.1955.11023008

Indirawati, Z., \& Nasihah, H. (2018). Strategi dan struktur kesantunan melayu dalam kritikan mentor: Rancangan realiti televisyen. GEMA Online ${ }^{\circledR}$ Journal of Language Studies, 18(2),134-153. http://ejournal.ukm.my/gema/article/view/20875

Iman, K. M. (2018). Politeness: Linguistic study. International Journal of Research in Social Sciences and Humanities, 8(IV),167-179. https://www.ijrssh.com/images/short_pdf/1538681625_11_Iman_Kareem_Mansoor. pdf

Ivana, P. (2012), Politeness strategies in interview questions. (Doctoral dissertation Masaryk, University Faculty of Arts). https://theses.cz/id/cdkbsw/?lang=en

Jefferson, G. (2004), Glossary of transcript symbols with an introduction. In G. H. Lerner Ed). conversation analysis: Studies from the First Generation. (pp: 13-31). Amsterdam: John Benjamins.

JobStreet. (2014). Tops five reasons fresh graduated don't get hired: JobStreet Survey, http://www.digitalnewsasia.com/digital-tops five reasons fresh graduated don't get hired.

Kerekes, J. (2007). The co-construction of a gatekeeping encounter: An inventory of verbal actions. Journal of Pragmatics, 39(11) 1942-1973. https://www.sciencedirect.com/science/article/abs/pii/S0378216607001270

Kerekes, J. (2006). Winning an interviewer's trust in a gatekeeping encounter. Language in Society, 35 (01) 27-57.

https://www.researchgate.net/publication/231900885_Winning_an_interviewer\%27s tru

st_in_a_gatekeeping_encounter

Lipovsky, C. (2006). Candidate's negotiation of their expertise in job interviews. Journal of Pragmatics, 38(8) 1147-1174. 
https://www.sciencedirect.com/science/article/abs/pii/S0378216605001232

MHEM. (2014). The national graduate employability blue print 2012-2017. Ministry of Higher Education Malaysia, Putra Jaya Malaysia, ISBN:978-967-0334-43-1.62.

Malaysian Examination Council. (2006). Malaysian University English Test (MUET) Regulations, test specifications, test format and sample questions. Selangor, Malaysia: Malaysian Examinations Council.

Majid, M. Z. A., Hussin, M., Norman, M. H., \& Kasavan, S. (2020). The employability skills among students of Public Higher Education Institution in Malaysia. Malaysian Journal of Society and Space, 16 (1), 36-45.

https://www.researchgate.net/publication/341670454_The_employability_skills_amo ng_students_of_Public_Higher_Education_Institution_in_Malaysia

Parisa, A., Azizollah, D., \& Zohreh, K. (2012). EFL Learners' realization of complaints in American English. GEMA Online ${ }^{\circledR}$ Journal of Language Studies, 12(2),711-725. https://www.researchgate.net/publication/287560287_Iranian_EFL_Learners\%27_Re alization_Of_Complaints_In_American_English

Tejan, Q. A., \& Sabil, A. (2019). Understanding employers' perception of employability skills and career development in Morocco. International Journal of Education \& Literacy Studies, 7(2), 135-138. http://journals.aiac.org.au/index.php/IJELS/article/view/5360

Sarfraz, I., Rajendran, D., Hewege, C., \& Mohan, M. D. (2018). An exploration of global employability skills: A systematic research review'. International Journal of Work Organisation and Emotion, 9(1), 63-88.

https://www.researchgate.net/publication/324579805

Selvaratnam, V. (2018). Our glaring English deficiency is too big to ignore. Malaysiakini. https://www.malaysiakini.com/news/440643

Shaari, A. H., Kamaluddin, M. R., \& Fauzi, W. F. P. (2019). Online-dating romance scam in Malaysia: An analysis of online conversations between scammers and victims. GEMA Online ${ }^{\circledR}$ Journal of Language Studies, 19(1),97-115. http://ejournal.ukm.my/gema/article/view/24360

Tanius, E. Johari, H., Yulia, A., Heng, C. S., \& Pazim, K. H. (2019). The employability skills performance of business graduates in Malaysia: do employers, graduates and academicians speak the same language?" International Journal of Asian Social Science, Asian Economic and Social Society, 9(1), 11-17.

Tejan, O. A., \& Sabil, A. (2019). Understanding Employers' Perception of Employability Skills and Career Development in Morocco. International Journal of Education \& Literacy Studies, 7(2), 134-138.

The Star. (2012). Education system not producing thinking graduates, say expert. The Star. http://thestar.com.my/news/story.asp?file=/2012/3/4/nation/20120304123742\&sec= nation The National Graduate Employability Blueprint 2012 - 2017 (2012). Ministry of Higher Education Malaysia, Putrajaya, UPM, Malaysia.

Yetty. (2018). Politeness strategy on social interaction used by Munanese. ELS Journal on Interdisciplinary Studies on Humanities, 1(1), 59-65.

https://www.academia.edu/37347222/Politeness_Strategy_on_Social_Interaction_Us ed_by_Munanese

Yule, G. (2008). Pragmatics. Oxford: Oxford University Press.

Wodak, R. (2013). Discourse analysis. London, UK; Sage. 
Zena, M., Moayad, N., Marlyna, M., \& Nor, M. N. F. (2012). Politeness in e-mails of Arab students in Malaysia. GEMA Online ${ }^{\circledR}$ Journal of Language Studies, 12(1),83-99. http://ejournal.ukm.my/gema/article/view/25 